more widely used in the future will depend in no small measure upon the way in which they are prepared and the technical skill which is at the service of committees in drafting first the statute, and then the report which explains it. ${ }^{22}$

\title{
REGULATION OF INTERSTATE SECURITY SALES- A RECENT REPORT
}

\section{HANS A. KLAGSBRUNN*}

$T$ HE offer and sale of securities to the people of a state, by one who never sets foot within the state, is a common occurrence. Such salesmen conduct their business exclusively by mail, telephone and telegraph, and locate their offices in a state which interests them, not as a market, but as a shelter only. Their transactions have so sorely vexed Blue Sky administrators that Congress has long considered taking control by means of a federal securities act.

What the federal government can do is another chapter; of interest here is a report, which recently issued from the Committee on Interstate Transactions, appointed by the National Association of Securities Commissioners. It concentrates the remarks of the thirty-three state officials who responded to a nation-wide questionnaire, and then offers a suggestion. Only in twenty-two states, it is there said, are the offers and sales of absentee salesmen within the pale of the statute. Only in six of them is enforcement, by injunction or cease and desist order, attempted.

Reasons for this administrative and legislative inaction, which has continued through a decade or more of security regulations, are hard to find. One turns first to the law reports to ascertain the effect of the commerce clause of the federal Constitution upon state power. Among the parties who sought to enjoin the enforcement of the Michigan Blue Sky statute in Merrick v. Halsey \&

${ }^{22}$ Cases on the use by courts of committee reports will be found collected in 7O A.L.R. 5. Other cases in the Federal District Courts are:

(Committee reports used): Regla Coal Co. v. Bowers, 37 F. (2d) 373 (S.D. N.Y., r929); Mennen Co. v. Fed. Trade Com., 288 Fed. 774 (C.C.A. 2d 1923), cert. denied, 262 U.S. 759, 43 Sup, Ct. 705, 67 L.Ed. I215 (r923); District of Columbia v. Newmann, 37 F. (2d) 444 (C.A.D.C., 1929 ), cert. denied, 28 I U.S. 833, 74 L.Ed. rr48 (r930); Riverside \& Dan River Cotton Mills v. United States, 37 F. (2d) 965 (Ct. Cl. I930), cert. denied, 282 U.S. 838, 75 L.Ed. 745 (r930); Nolan v. United States, 4I F. (2d) 962 (Ct.Cl. r930); The Silverbrook, I 8 F. (2d) ${ }_{44}$ (D.C.E.D. La. 1927); Lane v. Corwin, I Fed. Supp. r5I (July 5, 1932); Imhoff-Berg Co. v. United States, 43 F. (2d) 836 (D.N.J., r930); Jordan v. United States, 36 F. (2d) 43 (C.C.A. 9th 1929); United States ex rel. Patton v. Tod, 297 Fed. 385 (C.C.A. 2d r924).

(Committee reports not used): United States v. Burden, Smith \& Co., 33 F. (2d) 229 (C.C.A. $5^{\text {th }}$ 1929).

* Visiting Lecturer, the University of Chicago Law School. 
Co. ${ }^{x}$ was a brokerage house which conducted its business exclusively through interstate channels. ${ }^{2}$ It was denied relief, but the scant treatment it received in the opinion of the Supreme Court, suggested that later courts might not respect this portion of the holding. ${ }^{3}$ Subsequent litigation was expected; but it consists, to date, of only one case, Wrigley Pharmaceutical Co. v. Cameron. ${ }^{4}$ There, a Delaware corporation was flooding the mails of Pennsylvania with circulars from its New Jersey office. No official of the corporation came into the state in connection with this campaign, but its president and vice-president resided there. They were subpoenaed to appear before the Pennsylvania Securities Commission but refused to do so. The Commission threatened to procure a court order, and the president and vice-president, as well as the corporation, sought an injunction restraining such action. The court promised much by postulating as the question of the case "whether application of the Pennsylvania law to the plaintiffs is an illegal interference with interstate commerce," but it dismissed the action as "premature for the reason that it is impossible for the court to determine that it was the intention of the authorities of the state of Pennsylvania to undertake any direct interference with interstate commerce." The court foresaw further action by the Commission, but none was taken and the corporation voluntarily ended its activities in Pennsylvania. Although the issue is nol at rest, at least no curtailment of state authority has been judicially suggested.

One turns, once more, to the law reports, this time in search of jurisdictional limitations on state power. But apparently there are none, for cases that locate the crime at the abode of the victim are plentiful. Re Palliser 5 is one in a pertinent series of Supreme Court decisions. ${ }^{6}$ The defendant there mailed a letter in New York to a postmaster in Connecticut, to induce him to violate his official duty. The court ruled in favor of a Connecticut trial, and said: "There can be no doubt at all that, if any offense was committed in New York, the offense continued to be committed when the letter reached the postmaster in Connecticut;

242 U.S. 568, 37 Sup. Ct. 227, 6I L. Ed. 498 (I9I6).

2 The facts are nowhere indisputably stated. Mr. Justice McKenna says merely, "They [the brokers] have no place of business in this state and are not at the present time sending agents in to the state, but are endeavoring to sell securities there." 242 U.S. at 573, 37 Sup. Ct. at 229, $6 \mathrm{I} \mathrm{L.} \mathrm{Ed.} \mathrm{at} 50 \mathrm{I}$ (19I6). These remarks have, however, generally been thought to mean that "they were doing business exclusively by mail, telegraph, or telephone." See Reed and Washburn, Blue Sky Laws (1921), 26ra.

3 Reed and Washburn, Blue Sky Laws (I92I), at 260a-263a.

4 I6 F. (2d) 290 (D.C. M.D. Pa. xg26).

5 I36 U.S. 257, 10 Sup. Ct. 1034, 34 L. Ed. 5I4 (189o).

${ }^{6}$ Horner v. United States, I43 U.S. 207, I 2 Sup. Ct. 407, 36 L. Ed. 126 (I892); United States v. Thayer, 209 U.S. 39,28 Sup. Ct. 426, 52 L. Ed. 673 (1908); Strassheim v. Daily, 221 U.S. 280, 3 I Sup. Ct. 558, 55 L. Ed. 735 (I9I I). See also Burton v. United States, 202 U.S. 344, 26 Sup. Ct. 688, 50 L. Ed. 1057 (rgo6). 
and that if no offense was committed in New York an offense was committed in Connecticut." The state courts contribute their share in analogous cases.7

According to the report, many states have failed to adopt enforcement provisions because their effectiveness is thought to be limited to publicity. But on turning to the statute books, one sees that some legislatures are covering the discrepancy that exists between jurisdiction over the crime and jurisdiction over the person. At the instance of the Commissioners on Uniform State Laws, seven states have already permitted their Governors to surrender to another state "any person ... . charged on indictment found in such other state with committing an act in this state intentionally resulting in a crime in such other state ... notwithstanding that the accused was not in that state at the time of the commission of the crime, and has not fled therefrom."8

There is then no reason for the inaction which state officials have sought to explain by constitutional and jurisdictional limitations. The victim states are not defenseless.

The sheltering state is the recipient of the Committee's suggestion. It consists in changing Blue Sky statutes, which forbid "sales, offers, negotiations .... within this state," to read, "sales, offers, negotiations ... . within, or from this state." Only two states have thus amended their statutes.9 Legislative action is hampered, the report shows, by untested constitutional doubts and by the reluctance of a state to exercise its police power and to use its funds for the protection of a public that is beyond its jurisdiction.

The provision, once procured, has proved its value. The defendants in Stevens ข. Wallace ducted its business through publications and through extensive telephone and telegraph communications. Although its sole office was in New Jersey it sought

7 See, for example, State v. Davis, 77 W.Va. 271 , 87 S.E. 262 (I9I5); State v. Hall, $\mathrm{xr}_{4}$ N.C. 909 , I9 S.E. 602 (1894). Cf. State ex rel. Black v. Delaye, r93 Ala. 500,68 So. 993 (Igr 5); Lindsey v. State, 38 Ohio St. 507 (I882); Comm. v. Pettes, Ir 4 Mass. 307 (I874); Adams v. People, I N.Y. 173 (1848).

8 This passage is condensed from $\$ 6$ of the Uniform Criminal Extradition Act, 9 U.L.A. II I (1932). It has been enacted in the following states: Alabama, General Acts, 193x, No. 482, § 6; Idaho Code Ann., I932, I, §§ I9-4606; Maine Rev. Stat., r930, c. 150, § 6; New Mexico, Comp. Stat., I929, \$\$ 55-106; Pennsylvania Stat. Ann. (Purdon, I930), \& 125; South Dakota Comp. Laws, 1929, § 4637-M; Utah Laws, 1927, c. 6I, $\S 6$.

9 Connecticut Public Acts, I93r, c. r8x; New Jersey Comp. Stat. Supplement, r925-r930, \$186-roa (2). Six other states have reached the same result without amendment. The statutes in five of them forbid sales, negotiations, offers, advertisements, elc., "within the state." Arkansas Statutes (Castle, I927), § 8418K; New Hampshire Public Laws, I926, c. 284, §§ 6, I7; New York Consolidated Laws (Cahill, 1930), c. 2I, art. 23-A, §352; Vermont Acts of 1929 , No. 93, $\$ 6$; Wisconsin Statutes, I93I, c. 189 . That they can be construed to cover transactions "from the state" is not certain; that the statute of the remaining state, which forbids sales "to any person in the state" (Missouri Statutes Annotated, I932, c. 40, § 7725) is not open to such construction is certain.

10 106 N.J. Eq. 352, I50 Atl. 835 (I930). 
no customers among New Jersey residents and with similar precaution sent no agents into the states which supplied its patronage. The state of New Jersey procured the injunction it asked, and to the defendant's claim that they "had not injured any persons residing in the state of New Jersey," the court said: "Such indeed is a weak argument to exonerate the defendants from their scheme of defrauding the public generally, and I regard it as untenable."

Misgivings and misapprehensions have bred legislative and administrative inertia, and held state doors open to the passage of the very securities that cry for detention. "Aggressive experimental work," says the Committee, can close them, but the states have waited idly for congressional succor. 